\title{
EFFECTS OF DIFFERENT TYPES OF BIOCHAR ON BASIC PROPERTIES AND BACTERIAL COMMUNITIES OF BLACK SOIL
}

\author{
DU, Y. $.^{1,2, \#}-$ WANG, T. Y. ${ }^{1,2, \#}-$ ANANE, P. S. ${ }^{1,2}-$ LI, Q. ${ }^{1,2}-$ LIU, S. X. ${ }^{1,2^{*}}-$ WANG, C. Y..$^{1,2^{*}}$ \\ ${ }^{I}$ College of Resource and Environmental Science, Jilin Agricultural University, \\ Changchun 130118, China
}

${ }^{2}$ Key Laboratory of Soil Resource Sustainable Utilization for Jilin Province Commodity Grain Bases, Changchun 130118, China

*Corresponding author

e-mail: liushuxia2005824@163.com

${ }^{\#}$ These authors have contributed equally to this work.

(Received $30^{\text {th }}$ Jan 2019; accepted $8^{\text {th }}$ Mar 2019)

\begin{abstract}
In order to explore the effects of biomass carbon on the basic properties of black soil and bacterial diversity, in this study, the combination of indoor culture and high-throughput sequencing was used to analyze the nutrient changes and bacterial communities of black soil after adding biochar. The results showed that compared with $\mathrm{CK}$, soil $\mathrm{pH}$, organic matter and available potassium increased significantly after adding biochar $(\mathrm{P}<0.05)$, and catalase, invertase, urease, and phosphatase increased substantially, while polyphenol oxidase decreased. A total of 17 phyla, 51 known genera were detected by high-throughput sequencing, among which Proteobacteria was the dominant phyla. The dominant genera including Sphingomonas, Mizugakiibacter, Bacillus, Marmoricola, Rhodanobacter, and Streptomyces. From the analysis of bacterial diversity, it can be concluded that the bacteria ace, chaol, Shannon and Simpson index of black soil increased after adding biochar, compared with $\mathrm{CK}$ in redundancy analysis (RDA), $\mathrm{AN}, \mathrm{NO}_{3}{ }^{-}-\mathrm{N}, \mathrm{NH}_{4}{ }^{+}-\mathrm{N}$ had a greater impact on microbial communities. The microbial functional bacteria $\mathrm{AOA}$ and cbbl were significantly correlated with $\mathrm{pH}, \mathrm{SOM}, \mathrm{AN}, \mathrm{NH}_{4}{ }^{+}-\mathrm{N}$, and $\mathrm{NO}_{3}{ }^{-}-\mathrm{N}(\mathrm{p}<0.05)$. Therefore, the addition of biochar can not only improve soil nutrients but also plays an important role in maintaining the diversity of soil bacterial communities.
\end{abstract}

Keywords: biochar, enzyme activity, high-throughput sequencing, bacterial diversity, microbial functional genes

\section{Introduction}

As a good soil improver, biochar could not only improve soil $\mathrm{pH}$ and base saturation but also reduce soil aluminum saturation (Cantrell et al., 2012; Zwieten et al., 2010; Liang et al., 2006). Zhou et al. (2017) found that biochar can also increase soil respiration in temperate forests. In recent years, more and more scholars have found that biochar could reduce greenhouse gas emissions (Weber et al., 2018). Biomass carbon can promote nutrient availability and increase carbon sequestration and soil fertility (Tian et al., 2016). The restoration of heavy metal pollution in soils and sediments by biochar is also considered by more and more scholars (Oleszczuk et al., 2012). So many characteristics of biochar are applied to the improvement of soil. As a big agricultural country, China's black soil is one of the three black soils in the world. Because of the unscientific fertilization and other factors in recent years, black soil is also facing environmental pollution. Therefore, the material charcoal is of great significance to the improvement of soil. However, the research on the microbial community of black soil by biochar is relatively scarce. The diversity of the microbial community is different when different biochars are added to different soils. Castaldi et al. (2011) found that the 
addition of wood biomass charcoal had little effect on soil microbial communities, while the addition of cotton biomass charcoal increased microbial activity. Some scholars have shown that biochar can provide suitable habitat for microorganisms due to its high porosity and cation exchange capacity (Cui et al., 2013). Some scholars have also shown that adding biomass charcoal to fine textured soil reduces microbial activity (Wang et al., 2017). The effect of biochar on soil enzyme activity is also the focus of current scholars. According to recent research, the addition of biomass carbon increases the enzyme activity associated with the $\mathrm{N}$ and $\mathrm{P}$ cycles, while at the same time reducing the enzyme activity associated with the $\mathrm{C}$ cycle (Bailey et al., 2011). Anyway, some studies have the opposite result.

The relationship between physical and chemical properties of black soil, enzymatic activity, microbial community diversity, and functional bacteria and environmental factors can help to further understand the improvement mechanism of biochar on black soil, and explore the influence of environmental factors on microbial community. Good use of biomass carbon in black soil, and the relationship between environmental factors and functional bacteria can more clearly understand the mechanism of action of biomass carbon, enzyme activity plays an indispensable role in soil activity, through A series of detailed studies on black soil by biochar can clearly identify the types and amounts of biomass carbon that are beneficial to soil improvement. This experiment mainly used three kinds of biomass charcoal to explore the improvement effect of black soil. In order to provide theoretical basis to the application of charcoal in Agriculture.

\section{Materials and methods}

\section{Test soil and biochar}

\section{Test soil}

The test soil was a typical black soil and was collected from the long-term location test points $\left(43^{\circ} 47^{\prime} 42^{\prime \prime} \mathrm{N}, 123^{\circ} 20^{\prime} 45^{\prime \prime} \mathrm{E}\right)$ of the Jilin Agricultural University. Corn is the major crop mostly cultivated on this soil. The fertilizer mostly applied during corn production are $\mathrm{N} 180 \mathrm{~kg} \mathrm{hm}^{-2}, \mathrm{P} 39.3 \mathrm{~kg} \mathrm{hm}^{-2}, \mathrm{~K} 75 \mathrm{~kg} \mathrm{hm}^{-2}$, soil bulk density of $1.15 \mathrm{~g}$ $\mathrm{cm}^{-3}$. The soil sample was collected from $0-20 \mathrm{~cm}$ plow layer soil, and after air drying, it was sieved by $2 \mathrm{~mm}$. The basic physicochemical traits are shown in Table 1.

Table 1. Physicochemical characteristics of the test soil

\begin{tabular}{c|c|c|c|c|c|c|c}
\hline $\mathbf{p H}$ & $\begin{array}{c}\mathbf{S O M} \\
\left(\mathbf{g ~ k g}^{-1}\right)\end{array}$ & $\begin{array}{c}\mathbf{A N} \\
\left(\mathbf{m g ~ k g}^{-1}\right)\end{array}$ & $\begin{array}{c}\mathbf{A P} \\
\left(\mathbf{m g ~ k g}^{-1}\right)\end{array}$ & $\begin{array}{c}\mathbf{A K} \\
\left(\mathbf{m g ~ k g}^{-1}\right)\end{array}$ & $\begin{array}{c}\text { clay } \\
(\mathbf{\%})\end{array}$ & $\begin{array}{c}\text { silt } \\
(\%)\end{array}$ & $\begin{array}{c}\text { sand } \\
(\%)\end{array}$ \\
\hline 5.55 & 21.52 & 84.25 & 15.68 & 192.05 & 34.75 & 25.47 & 39.77 \\
\hline
\end{tabular}

SOM: Soil organic matter; AN: alkali-hydrolyzable nitrogen; AP: available phosphorus; AK: available potassium

\section{Test biochar}

Three kinds of biomass carbon were provided by Dalian Xinglongxi Development Co., Ltd. These included corn stover, rice husk, and pine wood pyrolyzed at 350$550{ }^{\circ} \mathrm{C}$. The basic physical and chemical properties of biomass carbon are shown in Table 2. 
Table 2. Physicochemical characteristics of the test biochar

\begin{tabular}{c|c|c|c}
\hline Measurement items & CB & RB & PB \\
\hline Ash (\%) & $41.61 \pm 1.2$ & $38.62 \pm 2.1$ & $11.60 \pm 1.0$ \\
pH & $9.82 \pm 0.6$ & $8.48 \pm 0.5$ & $8.08 \pm 0.8$ \\
Organic carbon $\left(\mathrm{g} . \mathrm{kg}^{-1}\right)$ & $463.54 \pm 1.6$ & $708.50 \pm 2.5$ & $210.20 \pm 1.4$ \\
Total phosphorus $\left(\mathrm{g} . \mathrm{kg}^{-1)}\right.$ & $16.20 \pm 1.1$ & $13.16 \pm 1.4$ & $11.07 \pm 1.7$ \\
AP $\left(\mathrm{mg} \cdot \mathrm{kg}^{-1}\right)$ & $219.97 \pm 2.2$ & $385.28 \pm 2.1$ & $5.01 \pm 1.8$ \\
$\mathrm{~N}(\%)$ & 1.37 & 1.33 & 0.39 \\
\hline
\end{tabular}

$\mathrm{CB}$ : corn stover biomass carbon; RB: rice husk biomass charcoal; $\mathrm{PB}$ : pine biomass carbon

\section{Training test design}

Bio-char-soil preparation: black soil over $2 \mathrm{~mm}$ sieve and biomass charcoal over 20 mesh sieve were initially obtained. The air-dried black soil sample was mixed with certain quantities of each biomass charcoal to obtain $1000 \mathrm{~g}$ for each treatment. A total of 7 treatments were included in the trial (Table 3). Treatments were put in plastic bowls and randomly placed in an incubator at constant temperature and humidity (Fig. 1). Samples were incubated at $25^{\circ} \mathrm{C}$ for 6 months and moisture was always adjusted to $70 \%$ of field capacity. We had three repeats per treatment (Note: $1.2 \%$ is $1.2 \%$ of total weight; $6.0 \%$ is $6.0 \%$ of total weight).

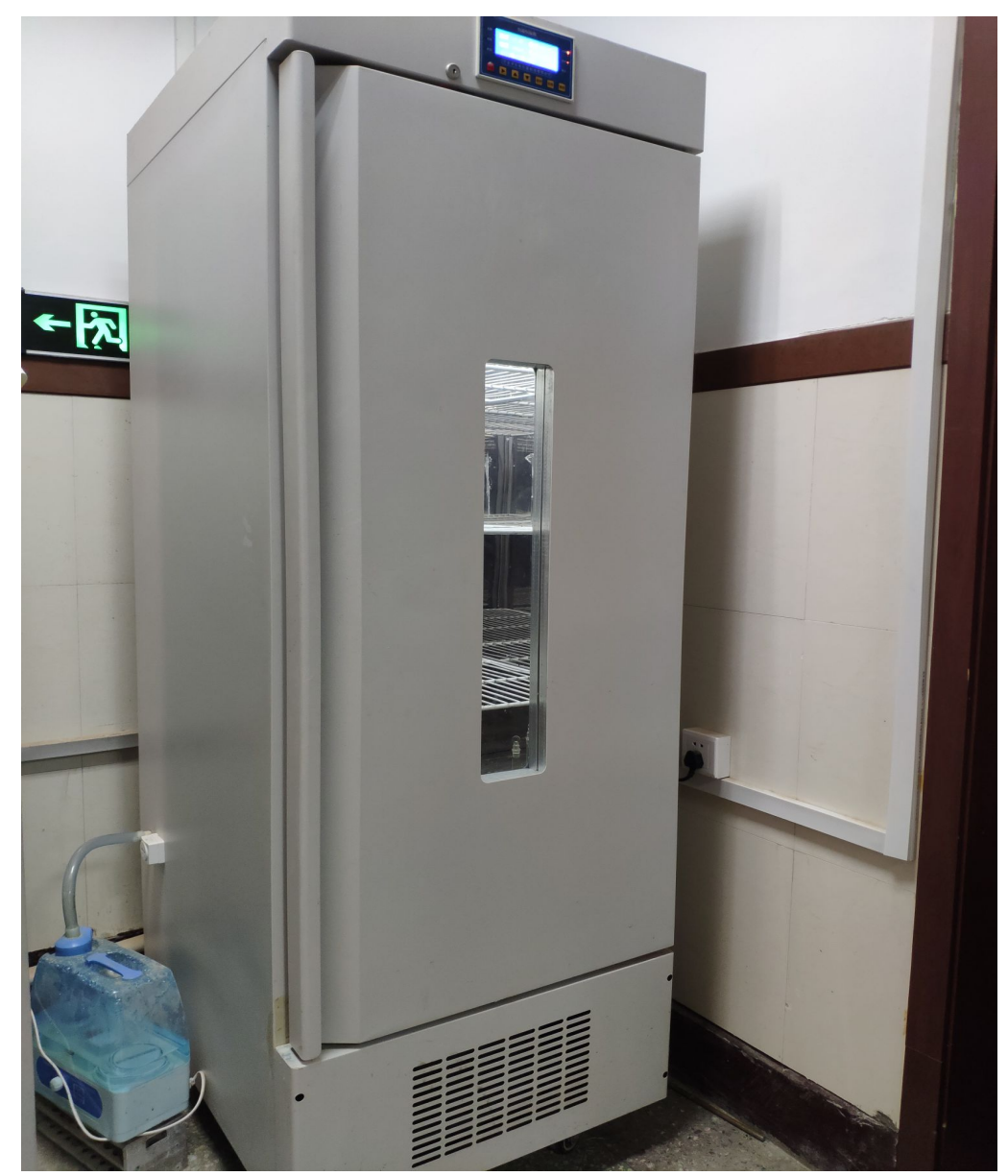

Figure 1. Constant temperature and humidity incubator 
Table 3. A total of 7 experimental treatments

\begin{tabular}{c|c}
\hline Treatments & Composition \\
\hline $\mathrm{CK}$ & Black soil \\
$1.2 \% \mathrm{CB}$ & Black soil $+1.2 \%$ corn stover biomass carbon \\
$6.0 \% \mathrm{CB}$ & Black soil $+6.0 \%$ corn stover biomass carbon \\
$1.2 \% \mathrm{RB}$ & Black soil $+1.2 \%$ rice husk biomass charcoal \\
$6.0 \% \mathrm{RB}$ & Black soil $+6.0 \%$ rice husk biomass charcoal \\
$1.2 \% \mathrm{~PB}$ & Black soil $+1.2 \%$ pine biomass carbon \\
$6.0 \% \mathrm{~PB}$ & Black soil $+6.0 \%$ pine biomass carbon \\
\hline
\end{tabular}

\section{Research methods}

The sampling of mixed culture soil

After the biomass carbon-black soil mixed treatments were cultured for six months, two soil samples were taken from each treatment. One for DNA extraction and the other for basic data determination. The soil was passed over $2 \mathrm{~mm}$ sieve for the removal of impurities. The same treatment was mixed three times in parallel. Samples for DNA extraction was stored at $-80^{\circ} \mathrm{C}$ and samples for basic data determination was air dried.

\section{Determination of basic data}

Soil $\mathrm{pH}$ was measured on a 1:2.5 (w/v) ratio in distilled water using a $\mathrm{pH}$ meter, Soil organic matter (SOM) was determined after dichromate oxidation and titration with ferrous ammonium sulphate, alkali-hydrolyzable nitrogen (AN) was determined alkaline solution diffusion method, available phosphorus (AP) was determined colorimetrically using the molybdate method, and available potassium (AK) was extracted by incubation with $1.0 \mathrm{~mol} \mathrm{~L}^{-1}$ ammonium acetate for $0.5 \mathrm{~h}$, followed by filtration, available potassium content was determined using a flame photometer (Brookes et al., 1985). Ammonium nitrogen and Nitrate nitrogen $\left(\mathrm{NH}_{4}{ }^{+}-\mathrm{N}\right.$ and $\left.\mathrm{NO}_{3}{ }^{-} \mathrm{N}\right)$ was extracted with 2 $\mathrm{M} \mathrm{KCl}$ and determined by flow injection analysis (TRAACA-2000, Germany). Polyphenol oxidase and Catalase were measured calorimetrically in a clear 96-well microplate according to Ai et al. (2015). Urease activity was determined according to Kandeler and Gerber (1988) and was expressed as mmole $\mathrm{NH}_{4}^{+} \mathrm{g}^{-1}$ dry soil $\mathrm{h}^{-1}$. Invertase activity was determined by using sucrose solution as the substrate as described by Chen et al. (2013). The activity of Phosphatase was measured by the transformation of disodium phenyl phosphate to phenol as described by Jin et al. (2016).

\section{Extraction and detection of total soil DNA}

Soil microbial DNA extraction was performed using the Power Soil DNA Isolation Kit from MOBIO, USA. $0.5 \mathrm{~g}$ of soil samples were weighed and stored in a refrigerator at $-80{ }^{\circ} \mathrm{C}$ to extract total DNA and purify soil genomic DNA (TIAN quick Midi Purification Kit, TIANGEN) according to the kit manual procedure; Detected by ultramicro spectrophotometer (Nanodrop 2000) DNA concentration $\geq 20 \mathrm{ng} \cdot \mu \mathrm{L}^{-1}, \mathrm{OD}_{260 / 280}$ between 1.8 and 2.0, and $\mathrm{OD}_{260 / 230}$ between 1.8 and 2.0. The extracted DNA was stored at $-20{ }^{\circ} \mathrm{C}$ for subsequent measurement. 


\section{High-throughput sequencing of the Illumina MiSeq platform}

The construction of a high-throughput sequencing library was completed by GENEWIZ Corporation (Shanghai, China). The V3-V4 hypervariable regions of the Bacteria 16S rRNA was amplified by PCR using 5 to $50 \mathrm{mg}$ of DNA as a template. The end of the PCR product of the 16S rRNA genes were amplified using the primer set U341F (ACTCCTACGGGAGGCAGCAG) and U806R (GGACTA CHVGGGTWTCTAAT). The library quality was detected using an Agilent 2100 Bioanalyzer (Agilent Technologies, Palo Alto, CA, USA) and the library concentration was detected by Qubit and real-time quantitative PCR (Applied Biosystems, Carlsbad, CA, USA). After the DNA library was mixed, double-ended sequencing (PE) was performed using the Illumina MiSeq (Illumina, San Diego, CA, USA) instrument instruction manual. Image analysis and base calling were performed using the MiSeq Control Software (MCS) in the MiSeq tool. Finally, an initial classification analysis was performed on the Illumina base space cloud computing platform.

All sequences were deposited in the NCBI sequence read Archive (SRA) database (Accession numbers: SRR7275367-SRR7275373).

\section{Real-time PCR amplification}

The abundances of genes (nifH, archaeal amoA (AOA), bacterial amoA (AOB), nosZ, $c b b l$ and $g d h 3$ ) encoding the key enzymes for biological N, P cycling were quantified by real-time PCR (IBA7500) for all soil samples. These methods were modified from their original descriptions (references following primers) (Table A1 in the Appendix). Gel-purified PCR producgts from a common DNA mixture (equal amounts of DNA from all samples) were used to prepare sample-derived quantification standards (YU et al., 2005). The copy number of genes in each standard was calculated by DNA concentration (ng $\mu \mathrm{L}^{-1}$, measured by Qubit) divided by average molecular weight (PCR product length and GC content was obtained from barcodedpyrosequencing results) of the amplified gene fragment (Mao et al., 2012).

\section{Data processing}

OTU analysis uses V-SEARCH (1.9.6) for sequence clustering (sequence similarity is set to $97 \%$ ), and the aligned $16 \mathrm{~S}$ rRNA reference database is UNITE ITS database (https://unite.ut.ee/), then RDP is used. Classifier (Ribosomal Database Program) Bayesian algorithm performs species taxonomy analysis on representative sequences of OTUs and gives statistics on the community composition of each sample at different species classification levels. The analytic diversity software Qiime (1.9.1) was used to calculate the alpha diversity indices such as Shannon, Chao1, Ace, Simpson, goodscoverage. The (Un) Weighted Unifrac analysis was used to compare whether there was a significant difference in microbial communities between samples. Based on the (Un) Weighted Unifrac sample distance matrix information, non-metric multi-scale (NMDS) analysis was used to demonstrate $\beta$ diversity. Correlation analysis between species and environment (RDA) was performed using Canoco 5.0 software. We use Excel 2010, SPSS19.0 for data statistics and analysis. 


\section{Results}

\section{Effect of biomass carbon addition on physical and chemical properties and enzyme activity of black soil}

The basic physical and chemical properties of the soil after adding biochar are shown in Table 4. After adding biochar, the $\mathrm{pH}$, organic matter and available potassium of black soil increased compared with $\mathrm{CK}$ treatment, and the effect of $6.0 \% \mathrm{CB}$ treatment was the most significant. After adding biochar, the available phosphorus content of soil increased significantly with $1.2 \% \mathrm{RB}, 6.0 \% \mathrm{RB}$, and $6.0 \% \mathrm{CB}$, while $1.2 \% \mathrm{CB}, 1.2 \%$ $\mathrm{PB}$, and $6.0 \% \mathrm{~PB}$ treatment decreased compared with $\mathrm{CK}$ treatment. After adding biochar, the alkaline nitrogen, ammonium nitrogen and nitrate nitrogen in the soil showed a decreasing trend, and their values were the highest compared with CK treatment.

Table 4. Basic physical and chemical properties of bio-carbon soil

\begin{tabular}{|c|c|c|c|c|c|c|c|}
\hline Treatment & pH & $\begin{array}{c}\text { SOM } \\
\left(\mathrm{g} \mathrm{kg}^{-1}\right)\end{array}$ & $\begin{array}{c}\mathrm{AN} \\
\left(\mathrm{mg} \mathrm{kg}^{-1}\right)\end{array}$ & $\begin{array}{c}\mathrm{AP} \\
\left(\mathrm{mg} \mathrm{kg}^{-1}\right)\end{array}$ & $\begin{array}{c}\mathrm{AK} \\
\left(\mathrm{mg} \mathrm{kg}^{-1}\right)\end{array}$ & $\begin{array}{c}\mathrm{NH}_{4}{ }^{+}-\mathrm{N} \\
\left(\mathrm{mg} \mathrm{kg}^{-1}\right)\end{array}$ & $\begin{array}{c}\mathrm{NO}_{3}^{-}-\mathrm{N} \\
\left(\mathrm{mg} \mathrm{kg}^{-1}\right)\end{array}$ \\
\hline $\mathrm{CK}$ & $5.31 \pm 0.02 \mathrm{~d}$ & $39.10 \pm 1.13 \mathrm{e}$ & $139.86 \pm 3.63 \mathrm{a}$ & $37.00 \pm 2.36 \mathrm{~b}$ & $238.79 \pm 4.07 \mathrm{e}$ & $29.00 \pm 2.25 \mathrm{a}$ & $167.58 \pm 16.06 \mathrm{a}$ \\
\hline $1.2 \% \mathrm{CB}$ & $5.64 \pm 0.02 \mathrm{~b}$ & $50.01 \pm 1.25 \mathrm{~d}$ & $119.76 \pm 2.28 \mathrm{~b}$ & $31.27 \pm 1.01 \mathrm{~b}$ & $375.36 \pm 7.69 \mathrm{~d}$ & $25.71 \pm 4.60 \mathrm{a}$ & $131.77 \pm 8.21 b c$ \\
\hline $6.0 \% \mathrm{CB}$ & $6.23 \pm 0.06 \mathrm{a}$ & $114.52 \pm 7.42 \mathrm{a}$ & $65.65 \pm 0.89 \mathrm{f}$ & $61.60 \pm 2.46 \mathrm{a}$ & $861.77 \pm 12.67 \mathrm{a}$ & $4.27 \pm 0.28 \mathrm{c}$ & $42.58 \pm 3.55 \mathrm{e}$ \\
\hline $1.2 \% \mathrm{RB}$ & $5.55 \pm 0.19 \mathrm{bc}$ & $60.13 \pm 4.45 \mathrm{c}$ & $94.60 \pm 2.79 \mathrm{c}$ & $69.33 \pm 12.20 \mathrm{a}$ & $549.87 \pm 45.57 \mathrm{c}$ & $13.12 \pm 1.71 \mathrm{~b}$ & $139.94 \pm 5.66 \mathrm{~b}$ \\
\hline $6.0 \% \mathrm{RB}$ & $5.68 \pm 0.01 \mathrm{~b}$ & $95.88 \pm 7.18 \mathrm{~b}$ & $76.15 \pm 2.85 \mathrm{e}$ & $65.20 \pm 2.84 \mathrm{a}$ & $710.77 \pm 2.91 \mathrm{~b}$ & $7.19 \pm 1.60 \mathrm{c}$ & $104.51 \pm 10.22 \mathrm{~d}$ \\
\hline $1.2 \% \mathrm{~PB}$ & $5.47 \pm 0.06 \mathrm{c}$ & $51.70 \pm 3.62 \mathrm{~d}$ & $94.90 \pm 0.22 \mathrm{c}$ & $31.10 \pm 1.50 \mathrm{~b}$ & $243.49 \pm 0.57 \mathrm{e}$ & $12.05 \pm 0.40 \mathrm{~b}$ & $104.97 \pm 6.31 \mathrm{~d}$ \\
\hline $6.0 \% \mathrm{~PB}$ & $5.57 \pm 0.03 \mathrm{bc}$ & $100.29 \pm 3.02 b$ & $88.65 \pm 4.69 \mathrm{~d}$ & $35.07 \pm 0.92 b$ & $257.92 \pm 0.58 \mathrm{e}$ & $12.81 \pm 2.06 \mathrm{~b}$ & $118.33 \pm 10.63 \mathrm{~cd}$ \\
\hline
\end{tabular}

The changes in soil respiration intensity and enzyme activity after adding biochar are shown in Table 5. After the addition of biomass charcoal, the respiration intensity of the soil was significantly enhanced by the addition of corn stover charcoal, while the addition of rice husk biomass charcoal was significantly enhanced by $1.2 \% \mathrm{RB}$, and $6.0 \% \mathrm{RB}$ treatment was lower than $\mathrm{CK}$ treatment. The treatment of adding pine biomass charcoal significantly reduced its respiratory intensity compared to $\mathrm{CK}$. After adding biochar, the catalase was increased compared with CK treatment, and the effect of $6.0 \%$ $\mathrm{CB}$ was the most significant. The addition of rice husk with $6.0 \% \mathrm{RB}$ increased the effect significantly, and the addition of pine charcoal increased the effect when $6.0 \% \mathrm{~PB}$ was added. The invertase activity of the soil had the best effect when corn straw charcoal was added and decreased with rice husk and pine charcoal as compared with $\mathrm{CK}$. The urease activity of soil also had the best effect when corn straw charcoal was added, and the effect of treatment with $6.0 \% \mathrm{CB}$ was the most significant. Adding biomass carbon has little effect on phosphatase, and treatment with $1.2 \% \mathrm{CB}$ was the most significant. Polyphenol oxidase is inversely proportional to the degree of humification of the soil, with $6.0 \% \mathrm{CB}$ being the best.

\section{Effect of biomass carbon addition on the abundance of bacteria in black soil}

As seen from Figure 2, a total of 17 known bacterial phylum were detected in the black soil supplemented with biochar, of which Proteobacteria was the dominant flora, and the Proteobacteria gate was occupied by $1.2 \%$ RB treatment compared with CK treatment. The proportion was up to $41.46 \%$, and the proportion in the $6.0 \% \mathrm{CB}$ treatment was relatively small at $40.56 \%$. The Bacteroidetes and Actinobacteria gates 
accounted for a large proportion in the CK treatment, which was $30.02 \%$ and $17.68 \%$, respectively. The Acidobacteria gate was at $1.2 \% \mathrm{CB}$. The proportion of $6.0 \% \mathrm{CB}$ treatment was $12.73 \%$ and $11.64 \%$, respectively. Firmicutes accounted for a large proportion of $1.2 \% \mathrm{RB}$ and $1.2 \% \mathrm{~PB}$ at $7.24 \%$ and $7.55 \%$ respectively.

Table 5. Changes in enzyme activity of soil added with biomass carbon

\begin{tabular}{c|c|c|c|c|c|c}
\hline Treatment & $\begin{array}{c}\text { Respiration } \\
\text { intensity } \mathbf{( \mathbf { m l ~ k g } ^ { - 1 } )}\end{array}$ & $\begin{array}{c}\text { Catalase } \\
\left(\mathbf{m l ~ g}^{-\mathbf{1}}\right)\end{array}$ & $\begin{array}{c}\text { Invertase } \\
\left(\mathbf{m l ~ g}^{-\mathbf{1}}\right)\end{array}$ & $\begin{array}{c}\text { Urease } \\
\left(\mathbf{m g ~ g}^{-\mathbf{1}}\right)\end{array}$ & $\begin{array}{c}\text { Phosphatase } \\
\left(\mathbf{m g ~ g}^{-\mathbf{1}}\right)\end{array}$ & $\begin{array}{c}\text { Polyphenoloxidase } \\
\left(\mathbf{m l ~}^{\mathbf{- 1}}\right)\end{array}$ \\
\hline $\mathrm{CK}$ & $98.99 \pm 7.84 \mathrm{~b}$ & $0.94 \pm 0.01 \mathrm{f}$ & $0.68 \pm 0.07 \mathrm{~d}$ & $2.01 \pm 0.11 \mathrm{c}$ & $9.85 \pm 0.71 \mathrm{bc}$ & $0.049 \pm 0.007 \mathrm{a}$ \\
$1.2 \% \mathrm{CB}$ & $114.67 \pm 5.75 \mathrm{a}$ & $1.02 \pm 0.02 \mathrm{~cd}$ & $1.05 \pm 0.03 \mathrm{a}$ & $3.15 \pm 0.12 \mathrm{a}$ & $10.84 \pm 0.08 \mathrm{a}$ & $0.028 \pm 0.007 \mathrm{bc}$ \\
$6.0 \% \mathrm{CB}$ & $119.27 \pm 3.77 \mathrm{a}$ & $1.12 \pm 0.01 \mathrm{a}$ & $1.03 \pm 0.05 \mathrm{a}$ & $3.43 \pm 0.25 \mathrm{a}$ & $9.98 \pm 0.28 \mathrm{abc}$ & $0.009 \pm 0.002 \mathrm{~d}$ \\
$1.2 \% \mathrm{RB}$ & $113.73 \pm 7.70 \mathrm{a}$ & $1.00 \pm 0.02 \mathrm{de}$ & $0.74 \pm 0.03 \mathrm{~cd}$ & $2.83 \pm 0.70 \mathrm{ab}$ & $10.38 \pm 0.91 \mathrm{abc}$ & $0.035 \pm 0.003 \mathrm{~b}$ \\
$6.0 \% \mathrm{RB}$ & $85.72 \pm 2.37 \mathrm{c}$ & $1.05 \pm 0.01 \mathrm{~b}$ & $0.59 \pm 0.01 \mathrm{e}$ & $2.06 \pm 0.07 \mathrm{c}$ & $8.91 \pm 0.40 \mathrm{~d}$ & $0.025 \pm 0.001 \mathrm{c}$ \\
$1.2 \% \mathrm{~PB}$ & $62.20 \pm 3.83 \mathrm{~d}$ & $0.98 \pm 0.02 \mathrm{e}$ & $0.79 \pm 0.01 \mathrm{c}$ & $2.32 \pm 0.16 \mathrm{bc}$ & $10.64 \pm 0.13 \mathrm{ab}$ & $0.046 \pm 0.008 \mathrm{a}$ \\
$6.0 \% \mathrm{~PB}$ & $65.96 \pm 3.45 \mathrm{~d}$ & $1.03 \pm 0.01 \mathrm{bc}$ & $0.86 \pm 0.02 \mathrm{~b}$ & $2.16 \pm 0.73 \mathrm{bc}$ & $9.47 \pm 0.19 \mathrm{~cd}$ & $0.022 \pm 0.005 \mathrm{c}$ \\
\hline
\end{tabular}

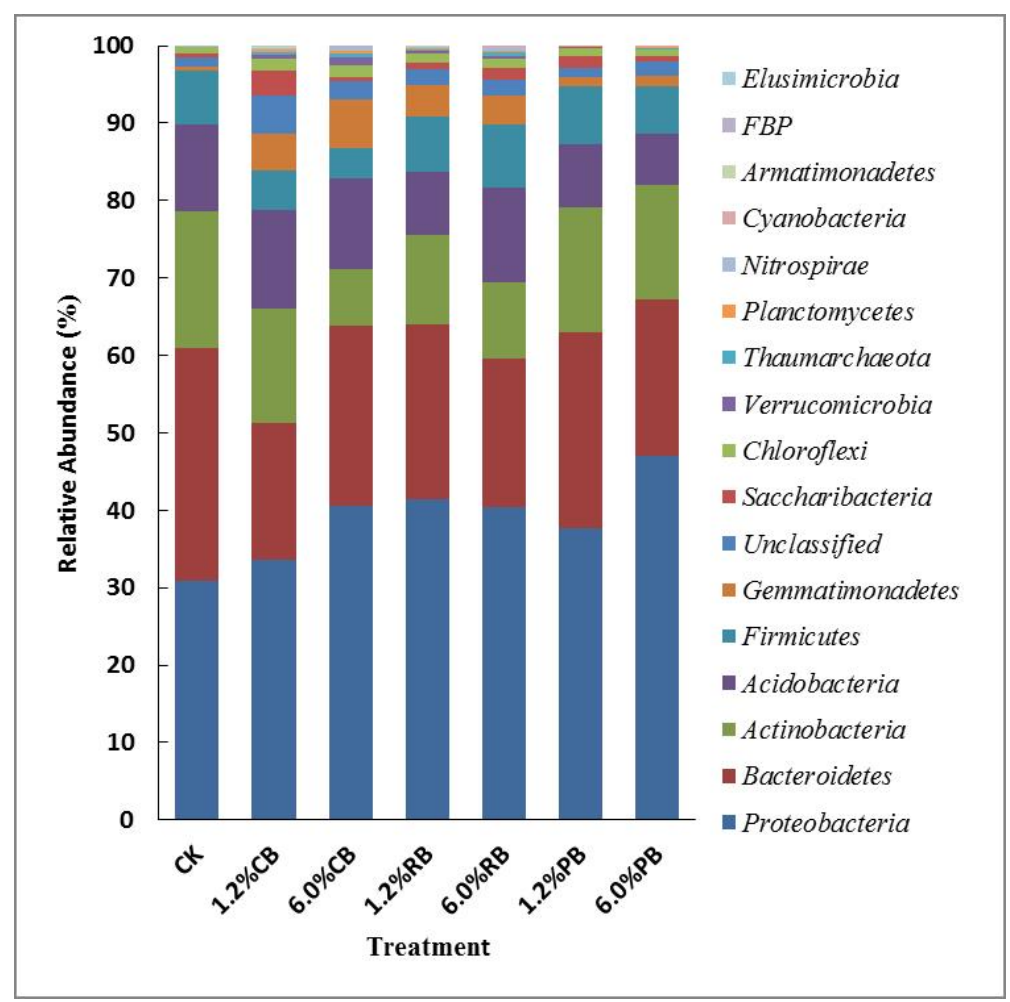

Figure 2. Relative abundance of bacterial community at phyla level. (CK: only black soil; $C B$ : black soil +corn stover biomass carbon; RB: black soil + rice husk biomass charcoal; PB: black soil + pine biomass carbon)

According to the abundance data of OTU, the heat map can cluster different OTUs at the genus level, and the heat map can reflect the relationship between the similarity, difference, and species clustering relationship of different treatments according to the color gradient. A total of 51 bacterial genera were detected from 7 samples in this sequencing. In this study, the top 30 bacterial genera with higher abundance were selected and the heat map was drawn using R language (Fig. 3). The dominant species 
included Sphingomonas, Mizugakiibacter, Bacillus, Marmoricola, Rhodanobacter, and Streptomyces, which accounted for $19.77 \%, 6.86 \%, 4.74 \%, 2.49 \%, 1.69 \%$, and 1.37 , respectively. It can be seen from the figure that, Sphingomonas is the lightest color in CK treatment, the darkest in $6.0 \%$ PB treatment and the darkest in Mizugakiibacter in CK treatment. The bacillus is the darkest in $6.0 \%$ treatment, at $6.0 \%$. The color is the lightest in $\mathrm{CB}$ treatment, the darkest color in the treatment of $1.2 \% \mathrm{~PB}$ of Marmoricola, the lightest in $6.0 \% \mathrm{CB}$ treatment; the darkest color of Rhodanobacter in CK treatment, the lightest in $6.0 \% \mathrm{~PB}$, Streptomyces The color is the deepest in the process, and the lightest in the $1.2 \% \mathrm{CB}$ process. In addition to the above-mentioned several abundance genus species that are significantly concentrated in different treatments, the other genus species also have branching aggregation similarities in different treatments.

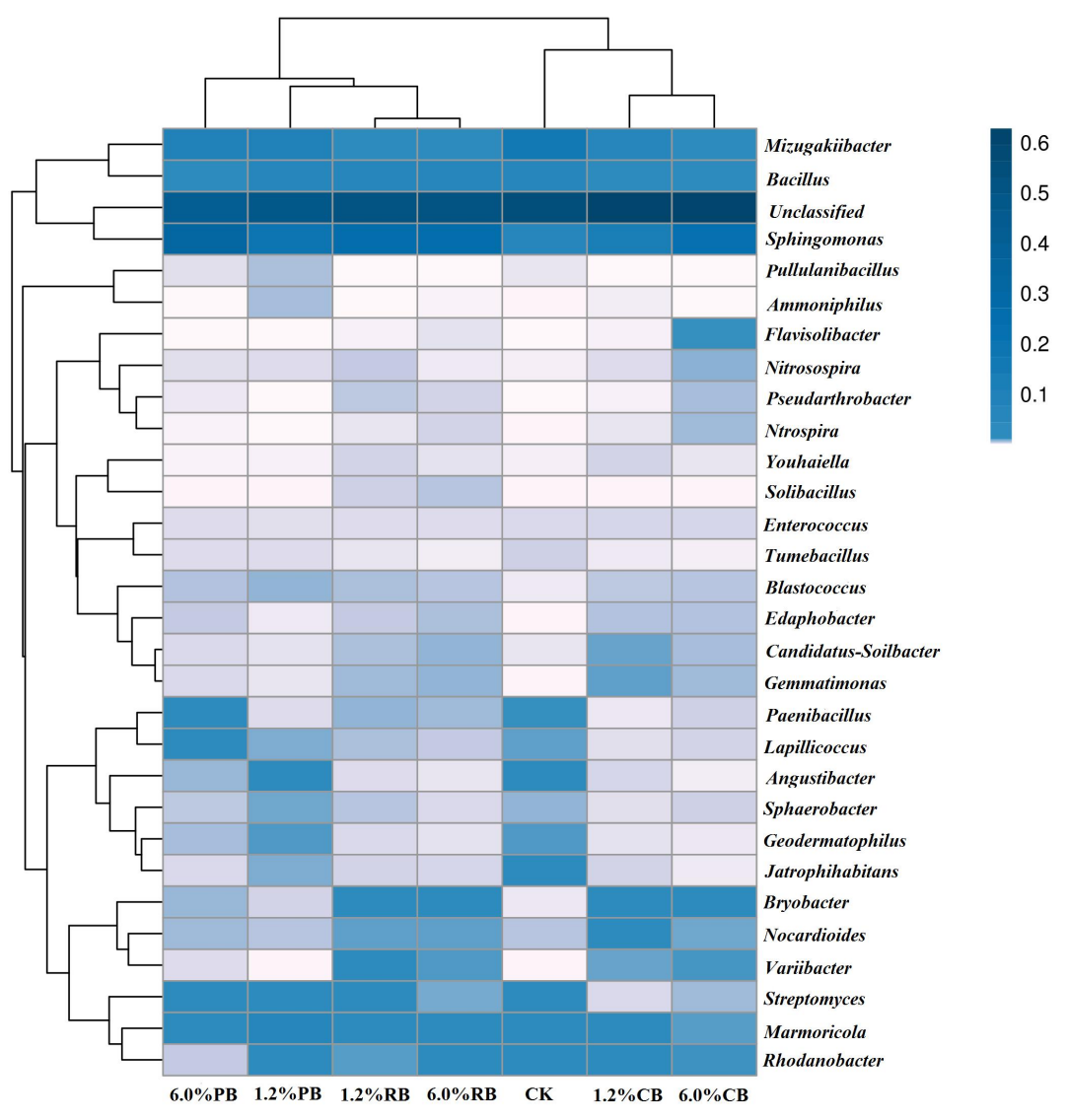

Figure 3. Heat map of black soil bacterial community level. (CK: only black soil; CB: black soil + corn stover biomass carbon; RB: black soil + rice husk biomass charcoal; PB: black soil + pine biomass carbon)

\section{The diversity of the bacterial community after adding biochar}

It can be seen from Table 6 that compared with CK treatment, after adding different kinds of biochar, the ace, chao1, Shannon and Simpson indices of black soil increased significantly, which shows that after adding biochar to black soil, the uniformity and richness of the soil have increased. Between the additions of different biochars, the ace and chao1 indices of $1.2 \% \mathrm{CB}$ and $1.2 \% \mathrm{RB}$ increased significantly, while the Shannon and Simpson indices of $1.2 \% \mathrm{CB}$ and $6.0 \% \mathrm{CB}$ increased most significantly. After 
adding different amounts of biochar, thus, after adding corn stover biomass charcoal, ace, chaol, Shannon, Simpson index of $1.2 \%$ CB treatment were greater than $6.0 \% \mathrm{CB}$ treatment; after adding rice husk biomass charcoal, the ace and chaol indices of $1.2 \%$ $\mathrm{RB}$ treatment were greater than $6.0 \% \mathrm{RB}$ treatment, while the Shannon and Simpson indices were less than $6.0 \% \mathrm{RB}$ treatment; after adding pine biomass carbon, the ace, chao1, and Shannon indices of $1.2 \%$ PB treatment were less than $6.0 \%$ PB treatment, only the Simpson index was greater than $6.0 \%$ PB processing.

Table 6. Statistical table of $\alpha$ diversity index of black soil bacteria

\begin{tabular}{c|c|c|c|c|c}
\hline Sample & Ace & Chao1 & Shannon & Simpson & Goods_coverage \\
\hline $\mathrm{CK}$ & 239.61 & 239.05 & 5.09 & 0.94 & 1.00 \\
$1.2 \% \mathrm{CB}$ & 275.83 & 277.14 & 6.42 & 0.98 & 1.00 \\
$6.0 \% \mathrm{CB}$ & 271.58 & 271.14 & 6.34 & 0.97 & 1.00 \\
$1.2 \% \mathrm{RB}$ & 277.48 & 277.11 & 6.07 & 0.96 & 1.00 \\
$6.0 \% \mathrm{RB}$ & 273.40 & 273.50 & 6.24 & 0.97 & 1.00 \\
$1.2 \% \mathrm{~PB}$ & 260.28 & 257.13 & 5.27 & 0.95 & 1.00 \\
$6.0 \% \mathrm{~PB}$ & 266.11 & 270.50 & 5.39 & 0.94 & 1.00 \\
\hline
\end{tabular}

The dilution curve uses a random sampling method for sequencing sequences to determine whether the sample size is sufficient and predicts the species richness. It can be seen from Figure 4 that when the sample Reads $<10000$, the number of OTUs increases rapidly with the increase of the sequencing depth. When $10000<$ Reads $<20000$, the number of OTUs increases slowly as the depth increases, when Reads $>20000$, as the depth of sequencing increases, the number of OTUs tends to be flat, indicating that the sequencing data at this time is more reasonable. The number of bacteria was higher when treated with $1.2 \% \mathrm{RB}$ and lower with $\mathrm{CK}$.

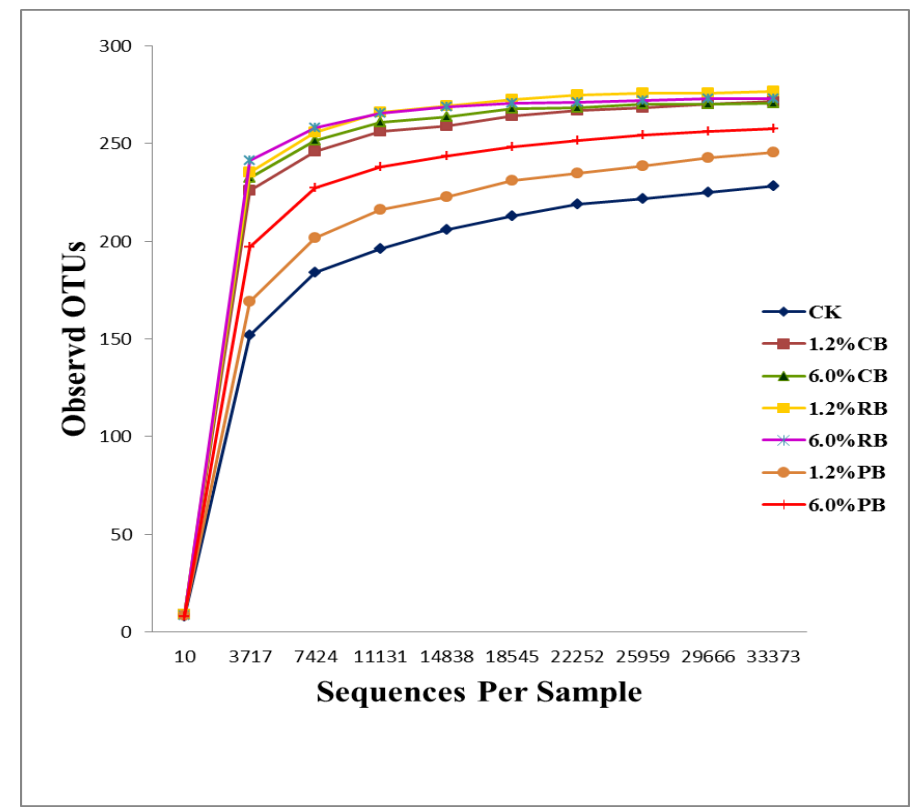

Figure 4. Dilution curve of soil bacterial in black soil. (CK: only black soil; CB: black soil + corn stover biomass carbon; RB: black soil + rice husk biomass charcoal; PB: black soil + pine biomass carbon) 


\section{Effects of environmental factors on bacterial community structure of black soil treated by different biomass carbon}

In order to analyze the effects of different biomass charcoal on black soil bacterial community, typical correspondence analysis was carried out in this study. The results are shown in Figure 5. As can be seen from the figure, the angle between the $\mathrm{pH}, \mathrm{SOM}$, $\mathrm{AP}$, and $\mathrm{AK}$ vector arrows is an acute angle, indicating that there is a synergistic effect between the four physical and chemical factors. The $6.0 \% \mathrm{CB}$ of the sample had the highest correlation with $\mathrm{pH}$ and $\mathrm{SOM}$, and the correlation between $6.0 \% \mathrm{RB}$ and $\mathrm{AP}$ was the highest. $\mathrm{CK}$ and $1.2 \% \mathrm{CB}$ had the highest correlation with $\mathrm{AN}, \mathrm{NO}_{3}^{-}-\mathrm{N}$ and $\mathrm{NH}_{4}{ }^{+}-\mathrm{N}$. The bacterial Variibacter belongs to the AP vector arrow with the smallest acute angle, indicating the highest correlation with AP. The correlation between Bryobacter and AK was the highest, the correlation between Nitrosospira and $\mathrm{pH}$ was the highest, the correlation between Sphingomonas and SOM was the highest, and the correlation between Rhodanobacter and Streptomyces was the highest with $\mathrm{AN}, \mathrm{NO}_{3}^{-}-\mathrm{N}$ and $\mathrm{NH}_{4}{ }^{+}-\mathrm{N}$, while $\mathrm{AN}, \mathrm{NO}_{3}{ }^{-}-\mathrm{N}$ and $\mathrm{NH}_{4}{ }^{+}-\mathrm{N}$ have an acute angle with most species, so AN, $\mathrm{NO}_{3}{ }^{-}-\mathrm{N}$ and $\mathrm{NH}_{4}{ }^{+}-\mathrm{N}$ have a greater impact on microbial communities.

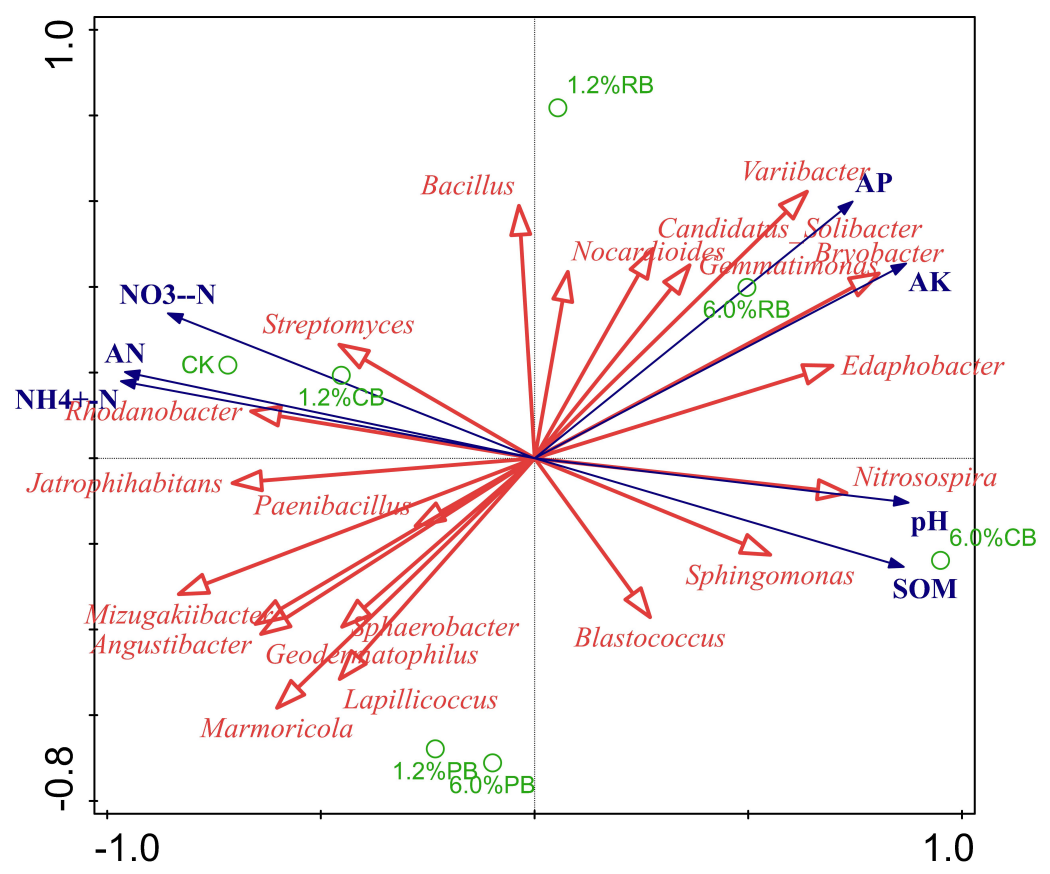

Figure 5. RDA analysis between environmental factors and bacterial genera levels (CK: only black soil; $C B$ : black soil +corn stover biomass carbon; RB: black soil + rice husk biomass charcoal; PB: black soil + pine biomass carbon; SOM: Soil organic matter; AN: Alkaline nitrogen; AP: Available phosphorus; AK: Available potassium; $\mathrm{NH}_{4}{ }^{+}-\mathrm{N}$ : Ammonium nitrogen; $\mathrm{NO}_{3}-\mathrm{N}$ : Nitrate nitrogen)

\section{Correlation analysis between soil functional microorganisms and environmental parameters}

Pearson correlation analysis was used to add a correlation between soil nutrient cycling functional genes and soil environmental parameters. It can be seen from Table 7 that the relative abundance of AOA is significantly positively correlated with $\mathrm{pH}$ 
$(\mathrm{r}=0.811, \mathrm{p}<0.05)$ and SOM $(\mathrm{r}=0.852, \mathrm{p}<0.05)$, and the relative abundance of AOA is related to $\mathrm{AN}(\mathrm{r}=-0.823, \mathrm{p}<0.005), \mathrm{NO}_{3}{ }^{-}-\mathrm{N}(\mathrm{R}=-0.857, \mathrm{P}<0.05)$ showed a significant negative correlation, cbbl relative abundance with $\mathrm{AN}(\mathrm{r}=-0.860, \mathrm{p}<0.05)$, $\mathrm{NH}_{4}{ }^{+}-\mathrm{N}(\mathrm{r}=-0.844, \mathrm{p}<0.05)$ showed a significant negative correlation.

Table 7. Correlation analysis between soil functional microorganisms and environmental parameters

\begin{tabular}{c|c|c|c|c|c|c|c}
\hline & Ph & SOM & AN & AP & AK & NH4+-N & NO3--N \\
\hline nifh & 0.530 & 0.410 & 0.116 & -0.153 & 0.268 & -0.210 & -0.611 \\
gdh3 & 0.550 & 0.239 & -0.095 & 0.620 & 0.699 & -0.016 & -0.165 \\
nosZ & 0.334 & 0.681 & -0.593 & -0.187 & 0.041 & -0.519 & -0.514 \\
$c b b l$ & 0.375 & 0.664 & $-0.860^{*}$ & 0.485 & 0.449 & $-0.844^{*}$ & -0.519 \\
AOB & 0.319 & 0.374 & -0.710 & 0.481 & 0.436 & -0.691 & -0.414 \\
AOA & $0.811^{*}$ & $0.852^{*}$ & $-0.823^{*}$ & 0.336 & 0.699 & -0.740 & $-0.857^{*}$ \\
\hline
\end{tabular}

SOM: Soil organic matter; AN: Alkaline nitrogen; AP: Available phosphorus; AK: Available potassium; $\mathrm{NH}_{4}{ }^{+}-\mathrm{N}$ : Ammonium nitrogen; $\mathrm{NO}_{3}{ }^{-}-\mathrm{N}$ : Nitrate nitrogen; nifh: Nitrogen-fixing bacteria; gdh3: Phosphateolytic bacteria; nosZ: Denitrifying bacteria; cbbl: Carbonaceous bacteria; AOB: Ammonia oxidizing bacteria; AOA: Ammonia-oxidizing archaea

\section{Discussion}

Khadem et al. (2017) added scorch and unburned biomass charcoal to the soil. The results showed that the addition of both biochars significantly increased the enzyme activity of the soil. Huang et al. (2017) found that urease activity remained stable when the amount of biomass carbon added was $1 \%$ by adding exogenous carbon. When the amount of biomass carbon increased to $5 \%$, urease activity increased significantly, while phosphoric acid. The activity of the enzyme temporarily decreased at the beginning, but eventually increased when the precipitate was treated with $1 \%$ biochar. When the concentration of biochar was as high as $5 \%$, the activity of alkaline phosphatase decreased to 0.75 times that of the control. Luo et al. (2016) found that peroxidase activity decreased with the increase of biomass carbon by adding different amounts of biomass charcoal, and the biomass carbon content was significantly negatively correlated with peroxidase activity. Wang et al. (2015) found that by adding biochar, biochar can increase soil $\mathrm{pH}$ and CEC. With the addition of biochar, $\mathrm{NH}_{4}{ }^{+}-\mathrm{N}$ in soil gradually decreases peroxidase and fractional oxidation. The activity of the enzyme decreases with the addition of biomass carbon, and the activity of urease increases with the increase of biomass carbon. This study is similar to the results of Wang et al. (2015). After adding biochar, the $\mathrm{pH}$ of the soil increased, and the $\mathrm{NH}_{4}{ }^{+}-\mathrm{N}, \mathrm{NO}_{3}^{-}-\mathrm{N}$, and $\mathrm{AN}$ in the soil decreased compared with $\mathrm{CK}$, and the polyphenol oxidase in the soil gradually decreased. Because the activity of polyphenol oxidase is negatively correlated with the degree of soil humification, as shown in Table 5, the polyphenol oxidase values of $6.0 \%$ $\mathrm{CB}, 6.0 \% \mathrm{~PB}$, and $6.0 \% \mathrm{RB}$ are significantly less than $\mathrm{CK}$, indicating that the degree of humification is the best. Catalase is related to soil respiration intensity and microbial activity. In this study, the highest catalase activity was treated with $6.0 \% \mathrm{CB}$, the value was $1.12 \mathrm{~mL} \mathrm{~g}^{-1}$, and the soil respiration intensity of $6.0 \% \mathrm{CB}$ treatment was $119.27 \mathrm{ml}$ $\mathrm{kg}^{-1}$. Both are higher than other treatments, which also indicates that the catalase activity is proportional to the soil respiration intensity. After adding three different biomass charcoal, the catalase activity was treated with $6.0 \%$ activity higher than $1.2 \%$, 
and $1.2 \%$ treatment was higher than $\mathrm{CK}$ treatment. Urease activity was also highest in $6.0 \% \mathrm{CB}$. Most of the urease activity was proportional to the organic matter content, and the organic matter content of $6.0 \%$ CB treatment was $114.52 \mathrm{~g} \mathrm{~kg}^{-1}$, which was higher than other treatments. The urease activity of the other rice husks and pine biomass carbon was treated with $1.2 \%$ treatment above $6.0 \%$.

Zhang et al. (2018) found that after adding biochar, the bacterial abundance of bacteria at the bacterial level increased correspondingly, and the effect of Chloroflexi gate abundance was significant. In this study, after adding biochar, Proteobacteria is the dominant population at the gate level, accounting for $47 \%$ of the $6.0 \% \mathrm{~PB}$ treatment, and $41.46 \%$ of the $1.2 \% \mathrm{RB}$, and the proportion in the CK treatment. Only $30.85 \%$, so adding biochar can increase the abundance of bacterial phylum levels. Taking Sphingomonas, a dominant genus of bacteria, as an example, the proportion in the $6.0 \%$ $\mathrm{PB}$ treatment was $31.22 \%$, the treatment in the $1.2 \% \mathrm{RB}$ was $24.58 \%$, and the proportion in the CK treatment was $4.74 \%$. The dominant genus Mizugakiibacter had the opposite result, accounting for $14.83 \%$ of the CK treatment, and the proportion of other treatments is smaller than the proportion of CK treatment. Therefore, the addition of biochar does not necessarily increase the bacterial abundance. Nguyen et al. (2018) found that soils supplemented with biochar had higher bacterial alpha diversity and OTU richness compared to $\mathrm{CK}$. Li et al. (2018) found that by applying biochar, the application of biochar increased the Shannon index of the bacteria compared to the control. This study is the same as the above two studies. After adding biochar, ace, chao1, Shannon, Simpson, CK treatment increased, and the ace index increased significantly with $1.2 \%$ RB treatment, both chao1, Shannon, Simpson were significantly increased by $1.2 \% \mathrm{CB}$ treatment. Du et al. (2018) found that the addition of different doses of biomass charcoal, will change the bacterial community during the composting process, but the composition of the bacterial community did not change much, and they found that the addition of biochar can also change the function such as sexual bacterial community. The smallest acute angle between the genus Variibacter and the AP vector arrow indicates the highest correlation with AP. The correlation between Bryobacter and $\mathrm{AK}$ was the highest, the correlation between Nitrosospira and $\mathrm{pH}$ was the highest, the correlation between Sphingomonas and SOM was the highest, and the correlation between Rhodanobacter and Streptomyces was the highest with $\mathrm{AN}, \mathrm{NO}_{3}{ }^{-}-\mathrm{N}$ and $\mathrm{NH}_{4}{ }^{+}-$ $\mathrm{N}$, while $\mathrm{AN}, \mathrm{NO}_{3}{ }^{-}-\mathrm{N}$ and $\mathrm{NH}_{4}{ }^{+}-\mathrm{N}$ had a great influence on the genus. The angle between the $\mathrm{pH}, \mathrm{SOM}, \mathrm{AP}$, and $\mathrm{AK}$ vector arrows is an acute angle, indicating a synergistic effect between the four physical and chemical factors. Fluorescence quantitative PCR was used to detect the abundance of functional genes in soil. Compared with CK, the application of biochar could significantly increase the abundance of functional genes in the soil, and the correlation between environmental factors and functional genes was analyzed by Pearson correlation. As seen from Table 7, the relative abundance of AOA is significantly positively correlated with $\mathrm{pH}$ $(\mathrm{r}=0.811, \mathrm{p}<0.05)$ and SOM $(\mathrm{r}=0.852, \mathrm{p}<0.05)$, and the relative abundance of AOA is related to $\mathrm{AN}(\mathrm{r}=-0.823, \mathrm{p}<0.005), \mathrm{NO}_{3}{ }^{-} \mathrm{N}(\mathrm{R}=-0.857, \mathrm{P}<0.05)$ showed a significant negative correlation, cbbl relative abundance with AN $(r=-0.860, p<0.05)$, $\mathrm{NH}_{4}{ }^{+}-\mathrm{N}(\mathrm{r}=-0.844, \mathrm{p}<0.05)$ showed a significant negative correlation, which also indicated that the relative abundance of AOA in soil had significant correlation with $\mathrm{pH}$, $\mathrm{SOM}, \mathrm{AN}, \mathrm{NO}_{3}^{-}-\mathrm{N}$, and cbbl had significant correlation with $\mathrm{AN}$ and $\mathrm{NH}_{4}{ }^{+}-\mathrm{N}$. Therefore, the application of biochar has a relatively large effect on the functional bacteria AOA and cbbl in the soil. 


\section{Conclusion}

Adding biochar can increase the $\mathrm{pH}, \mathrm{SOM}$ and $\mathrm{AK}$ of black soil, and the increase of AP value is not significant, but the content of $\mathrm{AN}, \mathrm{NH}_{4}{ }^{+}-\mathrm{N}$ and $\mathrm{NO}_{3}{ }^{-}-\mathrm{N}$ in the soil after adding biochar is less than that of CK. The addition of biochar can increase the enzyme activity in soil. The activity of polyphenol oxidase is negatively correlated with the degree of humification. The lower the value, the higher the degree of humification and was best at $6.0 \% \mathrm{CB}$. Adding biomass charcoal can also affect the microbial community diversity of black soil. After adding biochar, the $\alpha$ diversity index of black soil was increased compared with $\mathrm{CK}$, and environmental factors also have an effect on the microbial community. Microbial functional bacteria AOA, cbbl and $\mathrm{pH}, \mathrm{SOM}, \mathrm{AN}$, $\mathrm{NH}_{4}{ }^{+}-\mathrm{N}, \mathrm{NO}_{3}{ }^{-}-\mathrm{N}$ had a significant correlation. Based on the above basic properties and changes in microbial communities, in the various treatments of this experiment, the best effect was to add corn stover charcoal, and the best amount to add was $6.0 \% \mathrm{CB}$.

Acknowledgements. This work was supported by the article was supported by funding from the National key R\&D project sub-project (2017YFD0300405--4), Natural Science Foundation of Jilin Province, China (20170101077JC) and Natural Science Foundation of Jilin Province, China (subject to guide project 20170101004JC).

\section{REFERENCES}

[1] Ai, C., Liang, G .Q., Sun, J. W., He, P., Tang, S. H., Yang, S. H., Zhou, W., Wang, X. B. (2015): The alleviation of acid soil stress in rice by inorganic or organic ameliorants is associated with changes in soil enzyme activity and microbial community composition. Biology and Fertility of Soils 51(4): 465-477.

[2] Bailey, V. L., Fansler, S. J., Smith, J. L., Bolton, H. (2011): Reconciling apparent variability in effects of biochar amendment on soil enzyme activities by assay optimization. - Soil Biology and Biochemistry 43: 296-301.

[3] Brookes, P. C., Landman, A., Pruden, G., Jenkinson, D. S. (1985): Chloroform fumigation and the release of soil nitrogen: a rapid direct extraction method to measure microbial biomass nitrogen in soil. - Soil Biology and Biochemistry 17(6): 837.

[4] Cantrell, K. B., Hunt, P. G., Uchimiya, M., Novak, J. M., Ro, K. S. (2012): Impact of pyrolysis temperature and manure source on physicochemical characteristics of biochar. Bioresource Technology 107: 419-428.

[5] Castaldi, S., Riondino, M., Baronti, S., Esposito, F. R., Marzaioli, R., Rutigliano, F. A., Vaccari, F. P., Miglietta, F. (2011): Impact of biochar application to a Mediterranean wheat crop on soil microbial activity and greenhouse gas fluxes. - Chemosphere 85(9): 1464-1471.

[6] Cui, L., Yan, J., Yang, Y., Li, L., Quan, G., Ding, C., Chen, T., Fu, Q., Chang, A. (2013): Influence of biochar on microbial activities of heavy metals contaminated paddy fields. Bioresources 8(4): 5536-5548.

[7] Chen, J., Liu, X., Zheng, J., Zhang, B., Lu, H., Chi, Z., Pan, G., Li, L., Zheng, J., Zhang, X., Wang, J., Yu, X. (2013): Biochar soil amendment increased bacterial but decreased fungal gene abundance with shifts in community structure in a slightly acid rice paddy from Southwest China. - Applied Soil Ecology 71: 33-44.

[8] Du, J., Zhang, Y., Qu, M., Yin, Y., Fan, K., Hu, B., Zhang, H., Wei, M., Ma, C. (2018): Effects of biochar on the microbial activity and community structure during sewage sludge composting. - Bioresource Technology 272: 171-179.

[9] Huang, D., Huang, C., Zeng, G., Wan, J., Deng, L., Liu, L., Xu, P., Wang, R., Wan, J. (2017): Effects of rice straw biochar on indigenous microbial community and enzymes activity in heavy metal-contaminated sediment. - Chemosphere 174: 545-553. 
[10] Jin, Y., Liang, X., He, M., Liu, Y., Tian, G., Shi, J. (2016): Manure biochar influence upon soil properties, phosphor us distribution and phosphatase activities: a micro cosm incubation study. - Chemosphere 142: 128-135.

[11] Kandeler, E., Gerber, H. (1988): Short-term assay of soil urease activity using colorimetric determination of ammonium. - Biology and Fertility of Soils 6: 68-72.

[12] Khadem, A., Raiesi, F. (2017): Influence of biochar on potential enzyme activities in two calcareous soils of contrasting texture. - Geoderma 308: 149-158.

[13] Li, Y., Li, Y., Chang, S. X., Yang, Y., Fu, S., Jiang, P., Luo, Y., Yang, M., Chen, Z., Hu, S., Zhao, M., Liang, X., Xu, Q., Zhou, G., Zhou, J. (2018): Biochar reduces soil heterotrophic respiration in a subtropical plantation through increasing soil organic carbon recalcitrancy and decreasing carbon-degrading microbial activity. - Soil Biology and Biochemistry 122: 173-185.

[14] Liang, B., Lehmann, J., Solomon, D., Kinyangi, J., Grossman, J., O’Neill, B., Skjemstad, J. O., Thies, J., Luizão, F. J., Petersen, J., Neves, E. G. (2006): Black carbon increases cation exchange capacity in soils. - Soil Science Society of America Journal 70: 1719-1730.

[15] Luo, L., Gu, J. D. (2016): Alteration of extracellular enzyme activity and microbial abundance by biochar addition: implication for carbon sequestration in subtropical mangrove sediment. - Journal of Environmental Management 182: 29-36.

[16] Mao, Y., Yannarell, A. C., Davis, S. C., Mackie, R. I. (2012): Impact of different bioenergy crops on N-cycling bacterial and archaeal communities in soil. Environmental Microbiology 15(3): 928.

[17] Nguyen, T. T. N., Wallace, H. M., Xu, C. Y., Zwieten, L., Weng, Z. H., Xu, Z., Che, R., Tahmasbian, I., Hu, H., Bai, S. H. (2018): The effects of short term, long term and reapplication of biochar on soil bacteria. - Science of the Total Environment 636: 142-151.

[18] Oleszczuk, P., Hale, S. E., Lehmann, J., Cornelissen, G. (2012): Activated carbon and biochar amendments decrease pore-water concentrations of polycyclic aromatic hydrocarbons (pahs) in sewage sludge. - Bioresource Technology 111: 84-91.

[19] Tian, J., Wang, J., Dippold, M., Gao, Y., Blagodatskaya, E., Kuzyakov, Y. (2016): Biochar affects soil organic matter cycling and microbial functions but does not alter microbial community structure in a paddy soil. - Science of the Total Environment 556: 89-97.

[20] Wang, D., Fonte, S. J., Parikh, S. J., Six, J., Scow, K. M. (2017): Biochar additions can enhance soil structure and the physical stabilization of C in aggregates. - Geoderma 303: 110-117.

[21] Wang, X., Song, D., Liang, G., Zhang, Q., Ai, C., Zhou, W. (2015): Maize biochar addition rate influences soil enzyme activity and microbial community composition in a fluvo-aquic soil. - Applied Soil Ecology 96: 265-272.

[22] Weber, K., Quicker, P. (2018): Properties of biochar. - Fuel 217: 240-261.

[23] Yu, Z., Jrmichel, F. C., Hansen, G., Wittum, T., Morrison, M. (2005): Development and application of Real-Time PCR assays for quantification of genes encoding tetracycline resistance. - Applied and Environmental Microbiology 71(11): 6926.

[24] Zhang, G., Guo, X., Zhu, Y., Liu, X., Han, Z., Sun, K., Ji, L., He, Q., Han, L. (2018): The effects of different biochars on microbial quantity, microbial community shift, enzyme activity, and biodegradation of polycyclic aromatic hydrocarbons in soil. - Geoderma 328: 100-108.

[25] Zhou, G., Zhou, X., Zhang, T., Du, Z., He, Y., Wang, X., Shao, J., Cao, Y., Xue, S., Wang, H., Xu, C. (2017): Biochar increased soil respiration in temperate forests but had no effects in subtropical forests. - Forest Ecology and Management 405: 339-349.

[26] Zwieten, L. V., Kimber, S., Morris, S., Chan, K. Y., Downie, A., Rust, J., Joseph, S., Cowie, A. (2010): Effects of biochar from slow pyrolysis of papermill waste on agronomic performance and soil fertility. - Plant and Soil 327(1-2): 235-246. 


\section{APPENDIX}

Table A1. Primers and real-time PCR conditions used in this experiment

\begin{tabular}{|c|c|c|c|}
\hline Function genes & & Primers & Real-time PCR protocol \\
\hline \multirow{2}{*}{ nifH } & PolF & 5'-TG CGAY CCS AAR GCB GAC TC-3' & \multirow{12}{*}{$\begin{array}{c}94^{\circ} \mathrm{C} \text { for } 5 \mathrm{~min} ; 40 \text { cycles of } \\
94{ }^{\circ} \mathrm{C} \text { for } 30 \mathrm{~s}, 57{ }^{\circ} \mathrm{C} \text { for } 45 \mathrm{~s} \\
\left(54{ }^{\circ} \mathrm{C} \text { for } n i f H \text { gene, } 60{ }^{\circ} \mathrm{C}\right. \\
\text { for AOB }), 72{ }^{\circ} \mathrm{C} \text { for } 1 \mathrm{~min}\end{array}$} \\
\hline & PolR & 5'-ATS GCC ATC ATY TCR CCG GA-3' & \\
\hline \multirow{2}{*}{$\mathrm{AOA}$} & Arch-amoAF & 5'-STA ATG GTC TGG CTT AGA CG-3' & \\
\hline & Arch-amoAR & 5'-GCG GCC ATC CAT CTG TAT GT-3' & \\
\hline \multirow{2}{*}{$\mathrm{AOB}$} & amoA-1F & 5'-GGG GTT TCT ACT GGT GGT-3' & \\
\hline & amoA-2R & 5'-CCC CTC KGS AAA GCC TTC TTC-3' & \\
\hline \multirow{2}{*}{$\operatorname{nos} Z$} & nosZ-F & 5'-CGY TGT TCM TCG ACA GCC AG-3' & \\
\hline & nosZ-1622R & 5'-CGS ACC TTS TTG CCS TYG CG-3' & \\
\hline \multirow{2}{*}{$c b b l$} & $\mathrm{~K} 2 \mathrm{f}$ & 5'-ACCAYCAAGCCSAAGCTSGG-3' & \\
\hline & $\mathrm{V} 2 \mathrm{r}$ & 5'-GCCTTCSAGCTTGCCSACCRC-3' & \\
\hline \multirow{2}{*}{ Gdh3 } & Gdh-3F & 5'-GTCTGGCGTCGTCTGATTGTG-3' & \\
\hline & Gdh-3R & 5'-CAGGCGTGGATTCTGCGTT-3' & \\
\hline
\end{tabular}

